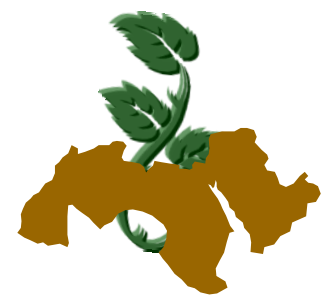

Arab Univ. J. Agric. Sci., Ain Shams Univ., Cairo, 17(1), 3-15, 2009

\title{
EFFICACY OF SOIL SOLARIZATION AND DAZOMIT (98\%) IN CONTROL OF ROOT-KNOT NEMATODE ON CUCUMBER UNDER THE OPEN FARMING CONDITIONS OF DEIR EZZOR, SYRIA
}

\author{
Al-Dakheel ${ }^{1}$, H.; A. Almhiemd ${ }^{1}$ and A. Alnajm ${ }^{1}$ \\ 1- Dept. Plant Protection, Faculty of Agric., Al-Furat University, Deir Ezzor, Syria
}

Keywords: Soil solarization; Dazomit (98\%); Rootknot nematode; Cucumber

\begin{abstract}
The immediate and long term evaluating trails based on efficacy of soil solarization process and the pesticide Dazomit (98\%) was worked out to control the root-knot nematode on cucumber. The temperature rised significantly $(4.0,12.2,13.3$, $20.9) \mathrm{C}^{\circ}$ at the soil depths of $(5,10,15,20) \mathrm{cm}$, respectively; when soil was covered with transparet plastic in July compared to nonsolarized soil (control). The results showed insignificant differences for the treatments combinations of soil solarization and the differences rates of Dazomit (98\%) and the
\end{abstract}

soil solarization alone in its ability in reducing numbers of the root-knot nematode after one month of soil solarization and the treating with Dazomit $(98 \%)$ reaching an efficacy ranged between $94-100 \%$ at the soil depth of $0-30 \mathrm{~cm}$. The results also indicated superior significancy of these treatments in preventing reforming the diseasecausing aggregates of these nematode during the second season, with growth rates ranged between (2-5.8)\% compared to(45-48.9)\% at the end of first season, and the incidence was reduced with rates (96-98) \% and the severity of infection rate (73$87) \%$ at the end of season compared to (100)\% in control treatment and indicated a high economic return (405\%) for the solarization treatment alone compared to 5,18 and $83 \%$ in the three treatment combinations, respectively. 